\title{
Există trăsături slavone în sintaxa limbii române? Două studii de caz ${ }^{\dagger}$
}

\author{
Adina Dragomirescu* \\ Institutul de Lingvistică „Iorgu Iordan - Al. Rosetti”, Calea 13 Septembrie 13, 050711 București, România \\ Facultatea de Litere, Universitatea din București, Str. Edgar Quinet 5-7, Sector 1, 010017 București, România
}

\section{Despre articol}

Istoric:

Primit 10 iunie 2014

Acceptat 8 iulie 2014

Publicat 13 ianuarie 2015

Cuvinte-cheie:

română veche

contact româno-slav

adjectiv categorial

dislocarea formelor verbale

inversiunea auxiliarelor

\begin{abstract}
Rezumat
În cercetarea de față este discutată problema influenței slavone asupra sintaxei limbii române (vechi). Se pornește de la ipoteza că multe dintre trăsăturile sintactice ale românei puse pe seama influenței slavone (mai ales în studii puternic influențate ideologic, apărute în perioada comunistă) sînt, de fapt, fie dezvoltări firești în trecerea de la latină la română, comune cu celelalte limbi romanice, fie rezultatul unor tendințe mai generale, manifestate în istoria limbilor indoeuropene. Se propune un algoritm de lucru pentru a verifica rolul influenței slavone în existența anumitor trăsături sintactice ale limbii române, care este aplicat la două cazuri concrete din limba română veche: topica adjectivelor relaționale și dislocarea formelor verbale compuse, corelată cu inversiunea auxiliarelor.
\end{abstract}

\section{Introducere}

În acest articol este adusă în discuție o problemă controversată a lingvisticii românești și romanice, existența unor elemente de origine slavonă în sintaxa limbii române vechi, eventual perpetuate și în limba modernă. Influența sintaxei slavone asupra românei vechi este relevantă în măsura în care, după cum se știe, multe dintre textele românești vechi (din secolul al XVI-lea) sînt traduceri religioase (și, în mai mică măsură juridice) după original slavon, iar în bibliografie (istorii ale limbii, studii filologice precedînd edițiile de text) numeroase trăsături sintactice ale românei vechi sînt considerate de origine slavonă. Pentru cercetarea de faţă, nu sînt importante trăsăturile sintactice care apar numai accidental într-un text vechi/într-un număr foarte mic de texte vechi, ci acele particularități generale ale limbii vechi, manifestate în mai multe texte, pe cît posibil variate ca registru. Numai două dintre aceste trăsături (care vor face obiectul unei cercetări mai ample) vor fi discutate în acest articol: topica adjectivelor relaţionale și dislocarea formelor verbale compuse.

Subiectul propus aici ridică două probleme, la care vom căuta răspunsuri: (i) o problemă de natură lingvistică—este posibil ca sintaxa limbii-țintă să fie influențată de sintaxa limbii-sursă, așa cum se întîmplă, în mod observabil, în lexic și semantică? și (ii) o problemă de natură istorico-ideologică-este posibil ca un anumit context politic/ideologic să influențeze interpretarea datelor dintr-un domeniu aparent independent de factorul politic, cum este lingvistica?

Înainte de a trece la analiza datelor de limbă, trebuie făcute cîteva observații legate de modul în care istoria, implicit contextul politic oscilant, au putut influența interpretarea lingvistică.

În istoriografia românească s-au manifestat două tendințe opuse, care au reapărut în mod ciclic, fiecare perioadă aducînd o interpretare proprie a datelor trecutului (Djuvara, 2006; Boia, 2011): pe de o parte, negarea oricărei influențe slave în istoria românească, mai ales în legătură cu formarea limbii române și a

${ }^{\dagger}$ Acest articol reprezintă forma revizuită a unei comunicări prezentate la Special Romance Seminar desfășurat la Universitatea din Oxford, pe 20 februarie 2014. Mulțumesc audienței de la acest seminar și, în special, profesorului Martin Maiden, pentru observații și sugestii. De asemenea, le mulțumesc pentru lectură și observații revizorilor anonimi ai revistei Diacronia.

*Adresă de corespondență: adina_drag@yahoo.com. 
poporului român (vezi poziția „puristă” a Școlii Ardelene) și, pe de altă parte, reacția de respingere a primei tendințe, manifestată prin proclamarea obiectivității istorice, care a generat supralicitarea rolului slav (membrii Junimii_-Gh. Panu, I. Bogdan, A.D. Xenopol; Noua Școală-P.P. Panaitescu, C.C. Giurescu). Jocul istoric este completat de alte poziţii: adoptarea unui slavism moderat (B.P. Hasdeu, N. Iorga), amplificarea influenței dace (V. Pârvan) sau exagerarea rolului culturii occidentale (T. Maiorescu, E. Lovinescu). Punctul culminant al „slavizării” istoriei românești a fost atins la începutul perioadei comuniste (P. Constantinescu-Iași, L. Pătrăşcanu, M. Roller), iar la sfirșitul anilor '60 ai secolului al XX-lea naționalismul excesiv a pus în umbră componenta slavă a limbii române, accentul revenind asupra importanței elementului dac.

\section{Influența slavă asupra românei. Stadiul actual al cercetării}

Cele două tendințe manifestate în istoriografie au funcționat și în domeniul lingvisticii: ca reacție la purismul latinist adoptat de Școala Ardeleană și de continuatorii acesteia, a apărut o exagerare a influenței slave (la sfîrșitul secolului al XIX-lea - începutul secolului al XX-lea, augmentată ulterior în perioada comunistă). Accentul a fost pus pe aspecte diferite: bilingvismul slavo-român („daco-slava”-Petrovici, 1943, vezi și Niculescu, 2007), amestecul etnic, implicînd populaţia dacă, slavă şi latină (Rosetti, 1968; Tagliavini, 1977) și influența slavă externă (Cihac, 1870; Densusianu, 1961). Tot ca reacție la purismul latinist a apărut și tendința de a exagera influența dacă (la începutul secolului al XX-lea, de către V. Pârvan și, ulterior, în perioada naționalistă a comunismului).

Date fiind aceste tendințe contradictorii, adevărul despre influența slavă asupra limbii române a rămas puțin cunoscut: românii, pe de o parte, și-au apărat originea și specificul național (vezi, pentru observații similare despre situația din Grecia, Mackridge, 2009), iar, pe de altă parte, au aderat la marile idei comuniste, supralicitînd influența slavă/rusească asupra „limbii naționale” (la fel ca în țările foste sovietice, vezi Sériot, 1995).

În lingvistica românească nu există studii speciale care să urmărească îndeaproape consecințele exagerării influenței slave sau, dimpotrivă, ale negării acesteia, în perioade diferite, cu excepția articolului Rodicăi Zafiu (2009), în care se vorbește despre efectele comunismului asupra cercetării lingvistice în general.

În lucrările de istorie a limbii române, trăsăturile de origine slavă sînt considerate ca manifestîndu-se în mai multe domenii:

(i) fonologie: vocala $\hat{\imath}$ (crîng), consoana $j(j a l e)$;

(ii) morfologie: păstrarea a două sau trei distincții cazuale în flexiunea nominală (Diaconescu, 1970, p. 198), desinența -o de la vocativ (soro!), structura internă a numeralelor cardinale de la unsprezece la nouăsprezece;

(iii) sintaxă: negația simplă, care apare sporadic în texte din secolul al XVI-lea (1) (Rizescu, 1963; Ciompec, 1969; Dragomirescu, 2008), forma reflexivă a multor verbe (a se căi, a se griji etc.) (Densusianu, 1961, I, p. 163; Pană Dindelegan, 2014), obiectul în dativ care corespunde unui obiect direct din limba modernă (a crede cuiva, a iubi cuiva) (Densusianu, 1961, I, p. 252-253; Pană Dindelegan, 2014);

(iv) lexic: influența slavă manifestată în toate domeniile, inclusiv în vocabularul de bază (drag, a iubi, a plăti, prieten, primi, scump);

(v) formarea cuvintelor: prefixe (ne-, răs-, prea- etc.), sufixe (-ac, -că,-eală, -ean etc.).

(1) fără de agiutoriulu celuia de susu niciu un lucru în calea vieţiei acestiia putemu să facemu $\left(\mathrm{CC}_{2}, 6\right)$

Chiar dacă, în perioada comunistă, a existat tendința de a exagera influența slavă, unii lingviști prestigioși au observat că anumite fapte lingvistice pot fi mai bine explicate ca fiind de origine latină, decît de origine slavă (vezi, de pildă, explicația din Rosetti, 1968, p. 303 pentru desinența de vocativ -e). Un demers de acelaşi tip, dar care ia în calcul mai multe date lingvistice, din domeniul sintaxei, ne propunem și în cercetarea de față. 
Deși, în studiile de istorie a limbii române și în studiile asupra edițiilor, există referiri la fapte sintactice de origine slavonă, totuși sintaxa este cel mai puțin investigat domeniu, deoarece nu este clar ce trăsături sînt explicabile numai prin influența slavonă, ce trăsături sînt de altă origine, dar au fost accentuate prin influența slavonă/slavă și ce trăsături au fost puse pe seama influenței slavone/slave exclusiv din motive ideologice (legate fie de ideologia culturală, de exemplu, în cazul Școlii Ardelene, fie de cea politică, de exemplu, în cazul falsificărilor din perioada comunistă).

\section{Două studii de caz}

Date fiind informațiile destul de neclare din bibliografie, precum și dificultatea de a separa realitatea lingvistică de falsa interpretare determinată de motive ideologice, propunem o cercetare de detaliu a fenomenelor sintactice considerate a fi de origine slavonă/slavă, care să răspundă la următoarele întrebări:

1. Care sînt (de fapt) trăsăturile sintactice ale limbii române care se explică prin influența slavonă și în ce măsură acestea sînt limitate la româna veche?

2. Ce algoritm de analiză se poate aplica pentru a separa trăsăturile autentic slavone/slave de cele puse pe seama influenței slavone/slave din motive ideologice?

3. Motivele care au determinat exagerarea influenței slave în lingvistică sînt aceleași cu motivele exagerării acestei influențe în istorie?

4. Este posibil ca studiul lingvistic să contureze o imagine mai clară a altor perioade istorice decît cea de formare a limbii și a poporului român (care se știe că a fost „reconstituită” mai ales cu date lingvistice)?

\subsection{Trăsături sintactice românești considerate de origine slavă}

Înainte de a trece la analiza propriu-zisă, este necesară inventarierea (provizorie a) fenomenelor sintactice care au fost considerate a fi de origine slavă. Informațiile sînt extrase din lucrări de istorie a limbii române (Densusianu, 1961; Rosetti, 1968; Gheție, 1997, Ivănescu, 2000), din studii speciale despre influența slavă în sintaxa limbii române (Seidel, 1958; Beneș, 1955; Copceac, 1998) și din studiile lingvistice ale textelor vechi editate (Mareș, 1969; Rizescu, 1971; Costinescu, 1981; Teodorescu \& Gheție, 1977; Chivu, 1993; Gheție \& Teodorescu, 2005).

În afară de construcțiile semnalate mai sus (vezi §2), lista fenomenelor sintactice de origine slavă mai cuprinde: poziția subiectului și a constituenților grupului nominal, (ne)dublarea complementului direct și indirect, marcarea cu pe a complementului direct, elipsa verbului copulativ $a f$, folosirea predicativă a infinitivului și a gerunziului, apariția infinitivului „scurt”, folosirea infinitivului în contexte specifice conjunctivului, inversiunea auxiliarului și a cliticelor pronominale, dislocarea formelor verbale compuse. Dacă toate aceste trăsături ar fi într-adevăr de origine slavonă, atunci s-ar putea spune că specificul sintactic al limbii române (mai ales vechi, dar și moderne) este în majoritate determinat de influența slavă.

\subsection{Algoritmul de lucru}

Pentru a determina mai precis amploarea influenței slavone/slave în sintaxa limbii române, propunem următorul algoritm: dacă o trăsătură apare în cel puțin trei dintre sursele indicate mai jos, atunci aceasta nu poate fi considerată de origine slavă. Sursele la care ne raportăm sînt:

(i) latina (tîrzie) (pentru care se folosesc informații mai ales din Ledgeway, 2012 și Adams, 2013);

(ii) alte limbi și dialecte romanice vechi (prin raportare la Company Company, 2006 pentru spaniola veche, Rohlfs, 1969, Buridant, 2000, Lardon \& Thomine, 2009, pentru franceza veche, Salvi \& Renzi, 2010, pentru italiana veche, Ledgeway, 2009, pentru vechea napoletană etc.);

(iii) texte româneşti originale vechi (din secolele al XVI-lea şi al XVII-lea, care se presupune că nu au fost supuse influenței slavone);

(iv) dialecte sud-dunărene (care, de asemenea, nu au suferit influența slavă, ulterioară separării dialectale); vom folosi cu precauție datele dialectale, pentru că, în unele situații, este posibil ca dialectele suddunărene să fi fost influențate de limbile slave moderne cu care au intrat în contact; dacă este vorba de o astfel de influență, atunci datele dialectale nu sînt relevante pentru algoritmul pe care îl propunem. 


\subsection{Studiu de caz 1: topica adjectivelor relaționale}

Spre deosebire de limba română modernă, în care adjectivele relaționale (de tipul omenesc, dumnezeiesc, românesc, literar etc.) sînt obligatoriu postnominale, în româna veche (pînă în secolul al XIX-lea) aceste adjective puteau apărea și în poziție prenominală (2); în momentul primelor texte românești conservate, poziția postnominală era deja mai frecventă (pentru o descriere detaliată, vezi Brăescu \& Dragomirescu, 2014).

(2) a. glăsi evreiasca limbă şi grăi ( $\left.\mathrm{CV}, 18^{\mathrm{v}}\right)$

b. Dumnezeiasca slujba ce e intru sfinţi (CL, $7^{\mathrm{v}}$ )

c. acesta, deaca auzi acea păgînească poruncă (svi, $\left.2^{\mathrm{v}}\right)$

d. făcîndu-i običnuită și politicească cinste (CG, 304)

În Niculescu (1999, p. 189-196) se arată că postpunerea adjectivului față de centrul nominal este determinată de influența slavonă. Observația nu este surprinzătoare, deoarece slavona permitea antepunerea adjectivelor față de centru, însă această ordine este marcată stilistic (Gamanovich, 2001, p. 315-318; Gasparov, 2001, p. 98), spre deosebire de româna veche, unde ordonarea adjectivelor pare a fi neconstrînsă.

Aplicînd însă algoritmul descris mai sus (\$3.2) se poate formula cu ușurință concluzia că fenomenul antepunerii adjectivelor relaţionale nu poate fi rezultatul direct al influenței slavone.

(i) Se știe că, în latină, adjectivele aveau topică liberă, care, eventual, era corelată cu diferențe de sens (3). Ceea ce este mai puțin clar este dacă variațiile de topică erau corelate cu diferențe de structură informațională sau cu alt tip de diferențe discursiv-pragmatice ori semantice. În acest sens, Ledgeway (2012, p. 50-51) a arătat că cel mai probabil în latină nu existau (încă) poziţii specializate pentru citiri contrastive ale adjectivelor, specializarea apărînd ulterior în varietățile romanice.

(3) a. protor urbanus (apud Ledgeway, 2012, p. 50)

b. urbanus pretor

'magistrat pentru cetățenii romani', 'magistrat spiritual'

(ii) Poziția prenominală a adjectivelor era posibilă și în alte varietăţi romanice vechi, cum sînt napoletana veche (Ledgeway, 2012, p. 56) (4a), italiana veche (4b) (Giusti, 2010, p. 604-605), franceza veche (4c) (Buridant, 2000, p. 173) etc.

(4) a. ...li spagnoli soldati (apud Ledgeway, 2012, p. 56)

'soldații spanioli'...

b. Dice lo maestro, che la citadina maniera di dire (...) (apud Giusti, 2010, p. 604-605)

'Maestrul spune că modul orășenesc de a spune...'

c. le feminin courage

'curajul feminin'

(Jeanne Baroin et Josiane Haffen, Boccace „Des cleres et nobles femmes”, 1401)

(iii) Poziția prenominală a adjectivelor este atestată și în documente originale vechi:

(5) a. svințitul împărătescul scaun (Dî, XC, p. 182)

b. sventei dumnezeiești mănăstire (Dî, XXXIX, p. 138)

c. Și aceasta împreună cu celelalte de lîngă ea este a domneștii și dumnezeieștii mănăstiri a celor Trei Ierarhi din Iași (ITM, p. 255) 
(iv) În dialectele sud-dunărene, topica adjectivelor față de centru este liberă (Martin Maiden, c.p.). Zegrean (2012, p. 91-92) observă că, în istroromână, probabil sub influența limbii croate, topica obișnuită a adjectivelor (inclusiv a celor relaționale) este prenominală (6), identificînd condițiile de apariție a adjectivelor în poziție postnominală. Și în meglenoromână (Atanasov, 1984, p. 536-537) topica obișnuită a adjectivului este prenominală, probabil sub influența limbii macedonene, însă și topica postnominală este destul de frecventă.

(6) Io cunosc ur taljanski fečror (apud Zegrean, 2012, p. 93)

'Eu cunosc un băiat italian'.

\subsection{Studiu de caz 2: dislocarea formelor verbale compuse și inversiunea auxiliarelor}

În această secțiune, sînt prezentate împreună două fenomene sintactice, aparent independente, care deosebesc româna veche de româna actuală, dislocarea formelor verbale compuse și inversiunea auxiliarelor (vezi, pentru detalii, Dragomirescu, 2013 și 2014, unde se arată că analiza sintactică a celor două fenomene este unitară, o unică schimbare parametrică fiind responsabilă de evoluția acestora).

Dacă în româna modernă dislocarea formelor verbale compuse se poate face numai prin clitice adverbiale (cunoscute în bibliografia românească drept semiadverbe-(7)), în româna veche posibilitățile de dislocare erau mult mai largi (8).

(7) a. Am cam greșit.

b. Vor mai cîștiga.

(8) a. de rroada voiu pîntecelui tău punre pre scaunul tău $\left(\mathrm{pH}, 113^{\mathrm{v}}\right)$

b. bogătatea se ară pre aproape curre, nu punereți înrima $\left(\mathrm{PH}, 51^{\mathrm{v}}\right)$

c. ce te-au tatăl tău tremis (CM, 240v)

d. de va grăunțul de grîu cădea la pămînt și nu va muri $\left(\mathrm{CC}_{1}, 116^{\mathrm{v}}\right)$

e. nece să ară cineva den morți învie $\left(\mathrm{CC}_{1}, 120^{\mathrm{v}}\right)$

f. Și cînd featele aceaste îndărăptu se înturnară la tatăl său, dzise tată-său: cum ați astădzi aşa curund venit acasă? (PO, 184)

g. cînd va omul să îmble pre toate voile $\left(\mathrm{FD}, 593^{\mathrm{v}}\right)$

În ceea ce privește inversiunea auxiliarelor, în româna actuală, aceasta este strict limitată la imprecații, în limba vorbită (9a), la interogații directe, în anumite arii dialectale (9b) și la textele religioase, unde apare ca o trăsătură conservatoare $(9 \mathrm{c})$. În româna veche, inversiunea auxiliarelor pare să fie un fenomen liber ((10) - favorizat totuși în propoziții principale, mai ales în poziție inițială, vezi Zafiu, 2014).

(9) a. Lua-te-ardracu'!

b. Fost-ai la tîrg?

c. Văzut-am lumina cea adevărată.

(10) a. Ințeles-ați aceastea toate? (СМ, 249 $)$

b. insă acmu asupră de-aceastea tipăritu-se-au ceastea doo cărți (po, 4)

c. Vrajbă pune-voi între tine și între muiarea (po, 20)

d. Feri-va Dumnedzău pre toți pre ceia ce-l iubăsc și pre toți nepocăiții va piiarde (Prav., 239v)

În cercetările anterioare care s-au ocupat de dislocarea formelor verbale compuse și/sau de inversiunea auxiliarelor (Moldovanu, 1977-1978; Gheție \& Zgraon, 1981; Zamfir, 2007; Frâncu, 2009), s-a arătat că această ordine atipică a constituenților fie este determinată de conservarea unei reguli sintactice arhaice, care ar fi fost generală în română înainte de primele texte păstrate (vezi mai ales Moldovanu, 1977-1978), fie se datorează influenței slavone, prin intermediul traducerilor. Cea de-a doua explicație se sprijină pe existența inversiunii auxiliarelor în slavonă (11); din păcate, pentru dislocări, nu am identificat informații relevante despre slavonă în bibliografia consultată. 
(11) ne srdoe li naju gore $\boldsymbol{p}_{\text {part }} \boldsymbol{b}_{\text {aux }}$ vbı naju

'Nu ne ardea inima în noi?' (Lc, 24, 32, apud Pancheva, 2008)

Totuşi, aplicarea algoritmului descris în $\$ 3.2$ duce către concluzia că influența slavonă constituie o explicație nesatisfăcătoare pentru fenomenele investigate.

(i) Despre latină se știe (Thielmann, 1885; Bauer, 2006; Adams, 2013) că structurile de tip habeo + obiect + participiu sînt atestate încă din perioada arhaică, însă, așa cum a fost demonstrat extrem de convingător de către Adams (2013, p. 646, passim), habeo nu avea statut de verb auxiliar, prin urmare nu avea constrîngeri de ordonare sau de adiacență. Pentru alte forme cu auxiliar (viitor, condițional), latina nu poate fi adusă în discuție pentru că aceste forme verbale s-au gramaticalizat ulterior, în limbile romanice, implicit și în română. Topica nemarcată a structurilor cu habeo era în latină participiu + habeo ((12)_vezi Bauer, 2006, p. 293, Adams, 2013, p. 648). Posibilitatea de a insera diferiți constituenți, mai ales obiectul direct, între participiu și habeo are atestări bogate în latină (vezi Bauer, 2006, p. 293, Adams, 2013, p. 649).

(12) omnes scaphas ad litus appulsas part $_{\text {babeant }}$ aux (Cæs., DBL.2.43.1, apud Bauer, 2006, p. 295)

'(că) ei au toate bărcile aduse la mal' (> 'ei au adus la mal toate bărcile')

(ii) Există numeroase varietăți romanice vechi care permit dislocarea formelor verbale compuse: spaniola veche $(13 a-b)$, italiana veche $(13 c-d)$, franceza veche $(13 e-f)$ etc.

(13) a. Porque elle non avia las cartas resçebidas (apud Mensching, 2012, p. 22)

'Pentru că ea nu primise scrisorile'

b. Eran sos fijos idos al canpo (apud Company Company, 2006, p. 328)

'Fiii săi se duseseră la cîmp'

c. avrebbono a Alessandro e forse alla donna fatta villania (apud Mensching, 2012, p. 22)

'ei l-ar fi înfruntat pe Alexandru și poate și pe doamnă'

d. Quali denari avea Baldovino lasciati loro (apud Poletto, 2006)

'ce bani le lăsase Baldovino'

e. pour la grant amour ai je pourchacié (apud Sitaridou, 2012, p. 588)

'Pentru marea iubire, am mers mai departe'

f. Un pou aprés eure de prime fu Mador venuz (apud Mensching, 2012, p. 32)

'Și imediat după prima oră a ajuns Mador'

De asemenea, numeroase varietăţi romanice vechi cunosc inversiunea auxiliarelor: spaniola veche $(14 a-c)$, italiana veche (14d), franceza veche $(14 \mathrm{e}-\mathrm{f})$ etc.

(14) a. Fecho as tú otro tal a los otros (apud Mensching, 2012, p. 22)

'Le-ai făcut la fel și celorlalți'

b. passada han la sierra (apud Company Company, 2006, p. 292)

'ei au traversat muntele'

c. cogida han la tienda (apud Company Company, 2006, p. 292)

'ei au pus jos cortul'

d. almeno quello che detto è_ non è inutile a sapere (apud Poletto, 2014)

'Cel puțin ceea ce s-a spus nu este inutil de știut'

e. por pooir que nos ä̈ons, recovree ne sera, se par ceste genz non (apud Frappier, 1976, p. 80) 'chiar dacă sîntem săraci, [cetatea] nu va fi cucerită, cel puțin nu de către acești oameni'

f. Le voir reconeü vos ai (apud Buridant, 2000, p. 377)

'I have confessed the truth to you' 
Ca și româna (care a pierdut posibilitatea dislocării și a inversiunii spre sfîrșitul perioadei vechi, 1780 în mod convențional), și celelalte limbi romanice au pierdut opțiunea pentru dislocare și au renunțat la ordinea participiu + auxiliar, ca ordine nemarcată, într-un anumit punct al evoluției, cel mai probabil, secolul al XV-lea, pentru spaniolă (Company Company, 2006, p. 287-299, 325-328) și secolul al XVI-lea pentru italiană (Poletto, 2006).

(iii) Atît dislocarea formelor verbale compuse (15), cît și inversiunea auxiliarului (16) sînt atestate în documente vechi românești:

(15) a. Iar de-ai hi domiata sîrguit să fii pînă acmu venit, avem nădeajde pre Dumnedzeu să fífost pînă acmu și la moșie. (Dî̀, XCIII, p. 184)

b. De va veni birdeni, vor Nicorizi Nevrudul a čeri čeva ban (Dî, CI, p. 193)

c. aceaea care-arăfi înnapoi rămas (Dî, XXXVI, p. 125)

(16) a. Pusu-ne-am și degetele mai jos (Dî, VI, p. 99)

b. cum veri zice, sta-vor au mearge-vor (Dî, XXXII, p. 127)

c. Aceste sfinte cărți ce se cheamă Minie datu-le-au Antiobie Jora (ITM, p. 362)

(iv) În ceea ce privește dialectele sud-dunărene, dispunem de informații relevante numai pentru istroromână și pentru meglenoromână. În istroromână, dislocarea este încă posibilă (17), iar poziția postverbală a auxiliarului din structura trecutului și a viitorului este un fenomen frecvent (18) (Sandfeld, 1930, p. 149; Caragiu Marioțeanu, 1975, p. 205; Caragiu Marioțeanu et al., 1975, p. 225; Kovaček, 1984, p. 576; Zegrean, 2012).

(17) a. Mâre voi io učide (apud Zegrean, 2012, preluat de la Sârbu, 1992)

'Mîine voi ucide'

b. An cârca cu bręnta am apa purtat (apud Zegrean, 2012, preluat de la Sârbu, 1992) 'Am cărat apa în cîrcă, în coș'

c. Ier-am musat cantat (apud Zegrean, 2012)

'Ieri am cîntat frumos'

(18) a. Ier citeit-nu-am nič (apud Zegrean, 2012)

'Nu am citit nimic ieri'

b. Datu-mi-a regalu, ne bocade vir (apud Zegrean, 2012)

'Mi-a dat cadoul, nu sticla de vin'

Și în meglenoromână auxiliarul de perfect este adesea postverbal în unele graiuri (19) (Sandfeld, 1930, p. 149; Caragiu Marioțeanu, 1975, p. 282; Caragiu Marioțeanu et al., 1975, p. 207; Atanasov, 1984, p. 523-527); în această varietate, viitorul are numai forme sintetice, deci nu este relevant pentru discuția de față. Atanasov (1984, p. 527) observă că topica este corelată cu distincții de modalizare: ordinea participiu + auxiliar este folosită atunci cînd vorbitorul se referă la un eveniment la care nu a luat parte (vezi 19c-d, unde contextul este mai larg), altfel spus, inversiunea auxiliarului este corelată cu evidențialitatea. Acest tip de distincție există și în macedoneană, o limbă slavă cu care meglenoromâna a intrat în contact; dacă această observaţie este adevărată, atunci datele despre meglenoromână nu sînt relevante pentru demonstraţia noastră.

(19) a. rugat-åm (apud Caragiu Marioțeanu et al., 1975, p. 225)

b. țirút-ai (apud Caragiu Marioțeanu et al., 1975, p. 225)

c. ier fóst-ăi la lúcru (apud Atanasov, 1984, p. 527)

d. țirút-ău si vină la noi (apud Atanasov, 1984, p. 527) 


\section{Concluzii}

În această secțiune finală încercăm să răspundem, cel puțin parțial, la întrebările formulate la începutul §3.

Datele prezentate sugerează că, înainte de a decide că o anumită trăsătură sintactică (a limbii române) este rezultatul unei influențe străine (slavone), ar trebui luate în calcul și alte scenarii, care au o putere explicativă mai mare. Pentru (daco)română, este evident că moștenirea latină, comparaţia cu alte limbi romanice vechi și moderne și comparația interdialectală sînt mult mai relevante decît simpla acceptare a afirmațiilor, adesea neargumentate și influențate ideologic, conform cărora anumite fenomene sintactice sînt de origine slavă/slavonă.

Algoritmul pe care l-am propus și pe care l-am aplicat la două fenomene considerate, în bibliografie, de origine slavonă, dar explicabile ca tendințe de evoluție comune limbilor romanice (subordonate, eventual, unor tendințe generale ale limbilor indoeuropene, de unde unele asemănări și cu slavona/limbi slave moderne) se poate aplica la întreaga listă de fenomene prezentate în $\$ 3.1$, eventual completată și cu alte fapte sintactice.

Dacă algoritmul propus nu este pe deplin convingător, se poate recurge și la o analiză sintactică de tip formal care, independent de datele din latină sau din alte limbi romanice, explică diferențele diacronice, recurgînd, de pildă, la conceptul generativ de schimbare parametrică (în care parametrul este înțeles ca o trăsătură formală a unei categorii funcționale, iar schimbarea parametrică este legată de distribuția trăsăturilor, care, diacronic, poate suferi anumite modificări-Roberts, 2012). În acest cadru, poziția obligatoriu postnominală a adjectivelor relaționale din româna modernă reprezintă rezultatul unei schimbări parametrice care a avut loc în română: pierderea unui anumit tip de deplasare (phrasal movement, mai precis $\mathrm{A}$ (djectival) $\mathrm{P}$ (hrase)-movement) din domeniul nominal (pentru detalii, vezi Brăescu \& Dragomirescu, 2014). În mod similar, pierderea posibilităţii de dislocare a formelor verbale compuse și inversiunea auxiliarelor pot fi explicate printr-o schimbare parametrică unică: dispariția unei trăsături responsabile pentru deplasare din domeniul C(omplementizatorului) — corelată cu dispariția inversiunii auxiliarului-și din domeniul verbal, mai precis $v$ (little $\boldsymbol{v}$, proiecție responsabilă cu atribuirea cazului Acuzativ)—corelată cu dispariția dislocărilor-(vezi, pentru detalii și bibliografie, Dragomirescu, 2013 și 2014).

Aplicarea algoritmului prezentat și găsirea unor explicații formale pentru fenomenele inventariate sub $\$ 3.1$ ne va permite o descriere mai coerentă a trăsăturilor limbii române (vechi), prin raportare la latină și limbile romanice, pe de o parte, și la slavonă și limbile slave moderne, pe de altă parte. Rezultatul așteptat al acestei cercetări este, fără îndoială, o listă de trăsături sintactice datorate influenței slavone mult mai limitată decît reiese din bibliografia precedentă.

Revenind asupra cauzelor care au determinat supralicitarea influenței slavone/slave în sintaxa românească, se poate afirma că motivele „falsificării” sînt în mare parte ideologice, dar la acestea se adaugă și lipsa-pînă de curînd a-unor informații sintactice relevante despre latină, despre limbile romanice (mai ales stadiile vechi) și chiar despre dialectele sud-dunărene, precum și preluarea, fără verificare, a unor informații din lucrări influențate ideologic.

Dacă rolul ideologiei în mistificarea sau interpretarea tezistă a unor date lingvistice reiese destul de clar, traseul invers este mai puțin evident: într-o anumită măsură, și datele lingvistice (unele controvesate, altele vizibil falsificate) au fost folosite pentru a susține anumite mistificări istorice, legate nu numai de istoria veche (formarea limbii și a poporului român, mai mult sau mai puțin supusă influenței slave, în funcție de necesitățile ideologice ale momentului), ci și de istoria mai recentă (în comunism, s-a accentuat rolul esențial al influenței slave în toate domeniile, vizibil și prin manifestările lingvistice).

\section{Bibliografie}

\section{A. Surse}

$\mathrm{CC}_{1}=$ Coresi, Tîlcul evangheliilor, în Coresi, Tîlcul evangheliilor și molitvenic românesc (1567-1568), ed. V. Drimba, Editura Academiei Române, București, 1998, p. 31-187. 
$\mathrm{CC}_{2}=$ Coresi, Carte cu invvățătură (1581), ed. S. Pușcariu, Al. Procopovici, Atelierele Grafice Socec \& Co., București, 1914.

$\mathrm{CG}=$ Literatura românescă de ceremonial. Condica lui Gheorgachi (1762), ed. Dan Simonescu, Fundaţia Regele Carol I, București, 1939.

$\mathrm{CL}=$ Coresi, Liturghier (1570), ed. Al. Mareș, Editura Academiei, București, 1969.

$\mathrm{CM}=$ Coresi, Molitvenic, în Coresi, Tîlcul evangheliilor și molitvenic românesc (1567-1568), ed. V. Drimba, Editura Academiei

Române, București, 1998, p. 189-211.

$\mathrm{Cv}=$ Codicele Voronețean (1563-1583), ed. M. Costinescu, Editura Academiei, București, 1981.

Dî = Documente și insemnări româneşti din secolul al XVI-lea, ed. Gh. Chivu, M. Georgescu, M. Ioniţă, Al. Mareș, A. Roman-

Moraru, Editura Academiei, București, 1979.

FD = Floarea darurilor (1592-1604), ed. A. Roman Moraru, Minerva, București, 1996 (Cele mai vechi cărți populare, I), p. 119-182.

ITM = Însemnăripe de pe manuscrise și cărți vechi din Țara Moldovei, un corpus editat de I. Caproșu și E. Chiaburu, Demiurg,

Iași, 2008, vol. I, (1429-1750), p. 130-582.

PH = Psaltirea Hurmuzaki (1500-1510), ed. I. Gheție și M. Teodorescu, Editura Academiei Române, București, 2005.

PO = Palia de la Orăștie (1582), ed. V. Pamfil, Editura Academiei, București, 1968.

Prav. $=$ Pravila ritorului Lucaci (1581), ed. I. Rizescu, Editura Academiei, București, 1971.

SVI = Varlaam și Ioasaf (1670), ed.: M. Stanciu Istrate, Reflexe ale medievalității europene in cultura română veche: Varlaam și

Ioasaf în cea mai veche versiune a traducerii lui Udriște Năsturel, Editura Muzeului Național al Literaturii Române, București, 2013.

\section{B. Lucrări de referință}

Adams, J. (2013). Social Variation and the Latin Language, Cambridge University Press, Cambridge, CrossRef.

Atanasov, P. (1984). Meglenoromâna, în: V. Rusu (ed.), Tratat de dialectologie românească, Scrisul Românesc, Craiova, p. 476550.

Bauer, B.L.M. (2006). 'Synthetic' vs. 'analytic' in Romance. The importance of varieties, în: R. Gess, D. Arteaga (eds), Historical Romance Linguistics. Retrospective and Perspectives, Benjamins, Amsterdam, p. 287-304.

Beneș, P. (1955). Incrucișarea slavo-română în forma infinitivului românesc, în „Studii și cercetări lingvistice”, VI, 3-4, p. 255 263.

Boia, L. (2011). Istorie și mit în conștiințta românească, ed. a III-a, Humanitas, București.

Brăescu, R. \& Dragomirescu, A. (2014). Sintaxa adjectivelor relaționale in limba română veche, în „Limba română, LXIII, 1, p. $27-47$.

Buridant, C. (2000). Grammaire nouvelle de l'ancien français, SEDES, Paris.

Caragiu Marioțeanu, M. (1975). Compendiu de dialectologie română (nord-și sud-dunăreană), Editura Științifică și Enciclopedică, București.

Caragiu Marioțeanu, M., Giosu, Ș., Ionescu-Ruxăndoiu, L. \& Todoran, R. (1977). Dialectologie română, Editura Didactică și Pedagogică, București.

Chivu, G. (1993). Studiu lingvistic, în Codex Sturdzanus, Editura Academiei Române, București, p. 142-230.

Cihac, Al. (1870). Dictionnaire d'etymologie daco-romane, Francfurt am Main/Berlin/Bucarest.

Ciompec, G. (1969), Observații asupra exprimării negației in limba română din secolele al XVI-lea - al XVIII-lea, în „Studii și cercetări lingvistice", XX, 2, p. 197-209.

Company Company, C. (ed.). (2006). Sintaxis histórica de la lengua española, FCE, UNAM, Mexico.

Copceac, D. (1998). Paralele slavo-române în sintaxa prepozițiilor, în Tipologia limbilor romanice, ed. a II-a, Clusium, Cluj, p. $198-229$.

Costinescu, M. (1981). Studiu lingvistic, în Codicele Voronețean, Editura Minerva, București, p. 89-213.

Densusianu, O. (1961). Istoria limbii române I, II, Editura Științifică, București.

Diaconescu, P. (1970). Structură şi evoluție în morfologia substantivului românesc, Editura Academiei, București.

Djuvara, N. (2006). Există istorie adevărată? Despre „relativitatea generală” a istoriei. Eseu despre epistemologie, ed. a II-a, Humanitas, București.

Dragomirescu, A. (2008). Concordanța negației în limba română veche, în G. Pană Dindelegan (ed.), Limba română. Dinamica limbii, dinamica interpretării, Editura Universității din București, p. 219-226.

Dragomirescu, A. (2013). O schimbare parametrică de la româna veche la româna modernă in sintaxa formelor verbale compuse cu auxiliar, în „Limba română”, LXII, 2, p. 225-239.

Dragomirescu, A. (2014). The syntax of compound tenses and scrambling in old Romanian, comunicare în cadrul SyntaxLab, University of Cambridge, Cambridge, 11 februarie 2014.

Frappier, J. (1976). Le style de Villehardouin dans les discours de sa chronique, în: Histoire, mythes et symbols. Études de literature française, Librairie Droz, Genève, p. 73-83.

Frâncu, C. (2009). Gramatica limbii române vechi (1581-1780), Casa Editorială Demiurg, Iaşi.

Gamanovich, (Archbishop Alypy). (2001). Grammar of the Church Slavonic language, English edition translated from Russian, Holy Trinity Monastery, Jordanville, New York. 
Gasparov, B. (2001). Old Church Slavonic, LICOM Europa, Munchen.

Gheție, I. (coord.) (1997). Istoria limbii române literare. Epoca veche (1532-1780), Editura Academiei Române, București.

Gheție, I. \& Zgraon, F. (1981). Despre așa-numitele formații premorfologice din limba română veche, în „Studii și cercetări lingvistice", XXXII, 2, p. 179-181.

Gheție, I. \& Teodorescu, M. (2005). Studiu lingvistic, în Psaltirea Hurmuzaki I, Editura Academiei Române, București, p. 23-83.

Giusti, G. (2010). Il sintagma aggetivale, în: G. Salvi, L. Renzi (eds), Grammatica dellitaliano antico, Il Mulino, Bologna, p. 593-616.

Ivănescu, G. (2000). Istoria limbii române, ed. a II-a, Editura Junimea, Iași.

Kovaček, A. (1984). Istroromâna, în: V. Rusu (ed.), Tratat de dialectologie românească, Scrisul Românesc, Craiova, p. 550-590.

Lardon, S. \& Thomine, M.-C. (2009). Grammaire du français de la Renaissance. Étude morphosyntaxique, Editions Classiques Garnier, Paris.

Ledgeway, A. (2009). Grammatica diacronica del dialetto napoletano, Max Niemeyer Verlag, Tübingen, CrossRef.

Ledgeway, A. (2012). From Latin to Romance. Morphosyntactic Typology and Change, Oxford University Press, Oxford, CrossRef.

Mackridge, P. (2009). Language and National Identity in Greece 1766-1976, Oxford University Press, Oxford/New York, CrossRef.

Mareș, Al. (1969). Studiu de limbă, în Liturghierul lui Coresi, Editura Academiei, București, p. 47-118.

Mensching, G. (2012). Parameters in Old Romance word order, în: C. Galves, S. Cyrino, R. Lopes, F. Sandalo, and J. Avelar (eds.), Parameter Theory and Linguistic Change, Oxford University Press, Oxford, p. 21-42.

Moldovanu, D. (1977-1978). Formațiile premorfologice din limba română veche, în „Anuarul de lingvistică și istorie literară”, XXVI, p. 45-69.

Niculescu, Al. (1999). Individualitatea limbii române între limbile romanice, vol. 3, Clusium, Cluj-Napoca.

Niculescu, Al. (2007). Románia slavica, în L'altra latinità. Storia linguistica del romeno tra Oriente e Occidente, Edizioni Fiorini, Verona, p. 95-104.

Pană Dindelegan, G. (2014). Variație în construcția verbului în limba veche, în R. Zafiu, A. Dragomirescu, A. Nicolae (eds.), Diacronie și sincronie în studiul limbii române, vol. I, Editura Universității din București, București (sub tipar).

Pancheva, R. (2008). Head-Directionality of TP in Old Church Slavonic, in: A. Antonenko, J. F. Bailyn, C. Y. Bethin (eds), Annual Workshop on Formal Approaches to Slavic Languages. The Stony Brook Meeting 2007, Michigan Slavic Publications, Ann Arbor, p. 313-332.

Petrovici, E. (1943). Daco-slava, în „Dacoromania”, X, II, p. 233-277.

Poletto, C. (2006). Parallel phases: a study on the hight and low left periphery of Old Italian, in: M. Frascarelli (ed.), Studies in Generative Grammar, Mouton de Gruyter, Berlin, p. 261-294.

Poletto, C. (2014). Word order in Old Italian, Oxford University Press, Oxford, CrossRef.

Rizescu, I. (1963). Cu privire la dubla negație în limba română, în „Studii și cercetări lingvistice”, XIV, 4, p. 471-478.

Rizescu, I. (1971). Studiu de limbă, în Pravila ritorului Lucaci, Editura Academiei, București, p. 35-145.

Roberts, I. (2012). Macroparameters and Minimalism, în: C. Galves, S. Cyrino, R. Lopes, F. Sandalo, and J. Avelar (eds), Parameter Theory and Linguistic Change, Oxford University Press, Oxford, p. 320-335.

Rohlfs, G. (1969). Grammatica storica della lingua italiana et dei suoi dialetti, vol. III, Sintassi e formazione delle parole, Turin.

Rosetti, Al. (1968). Istoria limbii române de la origini pînă în secolul al XVII-lea, Editura pentru Literatură, București.

Salvi, G. \& Renzi, L. (eds). (2010). Grammatica dell'italiano antico, Il Mulino, Bologna.

Sandfeld, Kr. (1930). Linguistique balkanique. Problèmes et resultants, Champion, Paris.

Sârbu, R. (1992). Texte istroromâne cu un studiu introductiv „Istroromâna - azi” și un glosar, ed. a II-a, Editura Universității din Timişoara, Timişoara.

Seidel, E. (1958). Elemente sintactice slave în limba română, Editura Academiei, București.

Sériot, P. (1995). Changements de paradigmes dans la linguistique soviétique des années 1920-1930, în Histoire epistémologie langage, XVII, 2, p. 235-251.

Sitaridou, I. (2012). A comparative study of word order in Old Romance, în „Folia linguistica”, 46, 2, p. 553-604, CrossRef.

Tagliavini, C. (1977). Originile limbilor neolatine - introducere în fiologia romanică, ed. a II-a, Editura Științifică și Enciclopedică, București.

Teodorescu, M. \& Gheție, I. (1977). Studiu de limbă, în Manuscrisul de la Ieud, Editura Academiei, București, p. 59-141.

Thielmann, Ph. (1885). Habere mit dem Infinitiv und die Entstehung des romanischen Futurums, în „Archiv für lateinische Lexicographie und Grammatik", 2, 372-423, 509-549.

Zafiu, R. (2009). Ideologie și mit în lingvistica românească, în „Communication interculturelle et littérature”, 2, 6, p. 313-324.

Zafiu, R. (2014). Auxiliary encliticization în 16th century Romanian: restrictions and regularities, în „Linguistica Atlantica”, 33, 2, p. 71-86.

Zamfir, D.-M. (2007). Morfologia verbului în dacoromâna veche (secolele al XVI-lea - al XVII-lea), Partea a II-a, Timpurile din sfera trecutului. Viitorul. Condiționalul, Editura Academiei Române, București.

Zegrean, I.-G. (2012). Balkan Romance: Aspects of the Syntax of Istro-Romanian, PhD Thesis, Università Ca'Foscari Venezia. 